\title{
THE MOTIVATION OF UNIVERSITY STUDENTS OF INTERNATIONAL RELATIONS TO LEARN ENGLISH
}

\author{
Zarina Markova, \\ South-West University, Blagoevgrad, Bulgaria \\ Dessislava Yaneva, \\ South-West University, Blagoevgrad, Bulgaria
}

\begin{abstract}
This article reports on the findings of a study investigating the motivation of Bulgarian undergraduates of International Relations to learn English as a second language (L2). First, we consider language learning motivation in the context of three influential theoretical developments in research on motivation. Then, we report on a small-scale survey aiming to define the motivational profile of students of International Relations through the lens of the L2 Motivational Self System. The analysis of the survey data reveals similarities with findings of previous research as regards the favourable attitude towards English language learning, the prominent role of the ideal L2 self in the motivational pattern, and some doubt over the relation between the ought-to L2 self and the intended learning effort. The study results also indicate relations between travel orientation and the ought-to L2 self, and between the two types of instrumental motivation which have not been reported in previous research. These motivation peculiarities are explained through the specifics of the surveyed group that refer to students' aspirations and potential careers in international relations.
\end{abstract}

Keywords: language learning motivation, L2 Motivational Self System, foreign language learning

Article history:

Received: 20 February 2020;

Reviewed: 17 March 2020;

Revised: 29 March 2020;

Accepted: 6 April 2020;

Published: 30 June 2020

\section{Contributor roles:}

Conceptualization: Z.M. (lead); Investigation: D.Y (lead)., Z.M. (supporting);

Methodology: Z.M, D.Y. (equal); Data curation: Z.M. (lead);

Formal Analysis: Z.M (lead), D.Y. (supporting); Project Administration Z.M., D.Y. (equal)

Resources: ZM (lead), Supervision: Z.M. (lead); Visualization: Z.M. (lead);

Writing original draft: Z.M. (lead); Writing - review and editing: S Z.M. (lead);

Copyright (C) 2020 Zarina Markova and Dessislava Yaneva

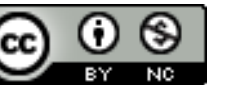

This open access article is published and distributed under a CC BY-NC 4.0 International License which permits non-commercial use, distribution, and reproduction in any medium, provided the original author and source are credited. Permissions beyond the scope of this license may be available at zarinamarkova@abv.bg. If you want to use the work commercially, you must first get the author's permission.

OpenData: Data for this study is available under a CC-BY-NC 3.0 license at Mendeley Data https:// doi.org/ 10.17632/69t8tvbwzf.1

Citation: Markova, Z, \& Yaneva, D. (2020). The Motivation of University Students of International Relations to Learn English. English Studies at NBU, 6(1), 5-28. https:/ / doi.org/ 10.33919/ esnbu.20.1.1

Zarina Markova, PhD in Methodology of FLT, is Chief Assistant Professor at the Department of German and Romance Studies, South-West University, Bulgaria. Her research interests lie in individual learner differences and foreign language education, teacher beliefs, and teacher education and development.

E-mail: zarinamarkova@ abv.bg (iD https:// orcid.org/0000-0003-0760-1274

Dessislava Yaneva holds a Master's degree in Language and Linguistics in the Global World. She is currently on maternity leave, but her previous affiliation was with the Faculty of Law and History at South-West University. Her research interests are in the field of second language acquisition.

E-mail: desi99@abv.bg

https:// orcid.org/ 0000-0002-3397-670X 


\section{Language Learning Motivation}

Language learning motivation has consistently been found to be one of the two major learner characteristics (the other being language aptitude) with the greatest influence on foreign language learning (Gardner \& Lambert, 1959, p. 266; Ellis, 2004, p. 531; Dörnyei, 2010, p. 247; Henry, 2011, p. 81). It accounts for only slightly less of the variance in learners' achievement scores than language aptitude (Ellis, 2004, p. 536), and has been argued to rank first as long as the motivation measure is related not only to language test results but also to situated learner behaviours (Dörnyei, 2010, p. 248). Whereas language aptitude is predominantly seen as a matter of innate endowment and, correspondingly, considered to be relatively fixed, motivation is regarded as more subject to change (Ellis, 2004, p. 534). It is therefore not surprising that motivation keeps attracting the attention of teachers and researchers alike - recognition of both its role in understanding language learning and its potential for making it more effective.

\section{Theoretical Overview}

The first rigorous attempts to study language learning motivation were made by Robert Gardner and Wallace Lambert (1959), who proposed that motivation is strongly influenced by two groups of reasons (or orientations, in Gardner and Lambert's terms) for learning the target language. The 'integrative' orientation refers to reasons that involve understanding of and interaction with the target language community, whereas the 'instrumental' orientation relates to the perceived need to learn a language for pragmatic reasons (e.g. to obtain a better job). Further elaboration of this proposal led to the sociopsychological model of second language acquisition (Gardner, 1985), whose most important feature is the distinction between motivation and two classes of attitudes, namely 'integrativeness' (i.e. the openness to the identification with the target language group) and 'attitudes towards the learning situation' (Masgoret \& Gardner, 2003). According to the model, integrativeness and attitudes towards the learning situation influence language achievement indirectly, through motivation. These three major components are generally measured by means of the Attitude/Motivation Test Battery (AMTB). The AMTB also measures the integrative and instrumental orientations, which do not necessarily reflect motivation (Masgoret \& Gardner, 2003, pp. 124-129).

In this article, we use the term 'second language' in its broader sense, i.e. a language other than the first language that has been acquired. We refer to 'foreign language' when formal, classroom context is discussed. 
Gardner's work has influenced motivation research enormously, in terms of both methodology and content (Skehan, 1991, p.283), and has been praised for laying down the foundations for L2 motivation research (Dörnyei \& Ushioda, 2013, p. 7). It has, however, received criticisms on several grounds, among which the irrelevance of the original distinction between integrative and instrumental orientation to some foreign language learning contexts, the failure to acknowledge the influence of success in language learning on motivation, and the lack of clear implications for foreign language pedagogy (Crokes and Schmidt, 1991, pp. 487-493; Skehan, 1991, pp. 283-285; Ellis, 2004, p. 537). It is therefore not surprising that the need for broadening the motivation research agenda has been recognised (Crokes \& Schmidt, 1991), which has consequently spurred further explorations of language learning motivation.

A good example of these explorations is the proposal of Noels et al. (2000). It is inspired by Edward Desi and Richard Ryan's (1985) self-determination theory, which postulates two general types of motivation: 'intrinsic', or based on the interest in the activity per se; and 'extrinsic', or based on factors external to the activity. Noels et al. (2000, p. 38) distinguish three types of intrinsic motivation (IM): IM-Knowledge (the motivation associated with the positive feelings when exploring new ideas and developing knowledge), IM-Accomplishment (the pleasure derived from trying to accomplish a task or achieve a goal), and IM-Stimulation (aesthetic appreciation and excitement stemming from performing a task). Correspondingly, Noels et al. (2000, pp. 39-40) recognise three types of extrinsic motivation (EM): external regulation, which relates to behaviours motivated by sources external to the person; introjected regulation, which refers to behaviours stimulated by some pressure incorporated into the self; and identified regulation, which pertains to behaviours caused by personally relevant reasons. The test of Noel et al.'s model confirmed the distinction between amotivation, less self-determined forms of motivation (external and introjected regulation), and more self-determined forms of motivation (identified regulation and IM) on the one hand, and the usefulness of the model for predicting educational outcomes, on the other hand. Their study findings also suggest that the more internalised the reason for language learning is, the more comfortable and persevering the respondents are (Noels et al., 2000, p.53) - in other words, that intrinsic motivation contributes most to language learning. 
Another influential proposal has been Zoltan Dörnyei's (2005) L2 Motivational Self System, which rests upon Gardner and Lambert's (1959) concept of integrative motivation, and the study of 'possible selves' (Markus \& Nurius, 1986) and 'future selfguides' (Higgins et al., 1985; Higgins, 1987) in mainstream psychology. The L2 Motivational Self System comprises three components:

1. The 'ideal L2 self' is the aspect of Higgins' 'ideal self' (Higgins et al., 1985) that relates to the use of a second language - if we envision ourselves as perfectly fluent users of a second language, the desire to minimise the discrepancy between our actual and ideal selves can serve as a drive for language learning. This component relates to hopes and aspirations, and has a promotion focus. Dörnyei (2009) suggests that Robert Gardner's integrative and internalised promotional instrumental motives are subsumed within the ideal L2 self.

2. The 'ought-to L2 self' refers to the L2 knowledge and skills we think we ought to possess to live up to expectations and avoid any negative results. It corresponds to Higgins' ought self (Higgins et al., 1985), which relates to safety, responsibility and obligations, and has a prevention focus. Again, our desire to narrow the gap between our actual and our ought-to selves can stimulate language learning. According to Dörnyei (2009), this component incorporates Noels et al.'s (2000) more extrinsic types of instrumental motivation.

3. The 'L2 learning experience' relates to the language learning context (the influence of the teacher, the class, the curriculum), and learner's perceptions of own language learning success or lack thereof. Dörnyei recognises the different level of conceptualisation of this component, and suggests its possible self aspects should be elaborated in future research (Dörnyei, 2009, p.29).

Dörnyei $(2009$, p.30) claims there is a certain degree of compatibility between his paradigm and Gardner's more recent version of the socio-psychological model (Masgoret \& Gardner, 2003), where the Attitude/Motivation Test Battery suggests three dimensions of motivated behaviour - integrativeness, instrumentality and attitudes towards the learning situation - which, according to Dörnyei, are similar to the L2 Motivational Self System. Additionally, Dörnyei finds some correspondence between his 
concepts of ideal L2 self, ought-to L2 self and L2 learning experience (p. 30), and Noel's (2001) identified regulation, introjected regulation and intrinsic motivation respectively. Dörnyei (2009, p.30) also draws parallels between the L2 Motivational Self System and Ema Ushioda's (2001) motivation construct. The eight motivation dimensions in the latter model - namely, academic interest, language-related enjoyment/liking, desired levels of L2 competence, personal goals, positive learning history, personal satisfaction, feelings about L2 (French, in Ushioda's context) speaking countries and people, and external pressures and incentives - could be subsumed, Dörnyei claims, into three categories: actual learning process, external pressures/ incentives, and integrative disposition. They, in turn, could be easily matched to the three components of the L2 Motivational Self System.

The L2 Motivational Self System has been tested and validated in a variety of contexts: in six different countries, with over 16500 participants representing different learner groups: secondary students from rural and urban areas, English-major/nonEnglish-major university students, and adult learners. (Al-Shehri, 2009; Csizér \& Kormos, 2009; Ryan, 2009; Taguchi et al., 2009; Lamb, 2012; You \& Dörnyei, 2016). Additionally, there has been evidence for its compatibility with Gardner's and Noel's paradigms (Ryan, 2009; Taguchi et al., 2009), which could allow new meaningfulness of previous research results within the self framework (Dörnyei, 2009, p.38). Other studies, however, have not found a prominent relationship between the ought-to L2 self and motivated behaviour (Csizér \& Kormos, 2009; Csizér \& Lukács, 2010; Lamb, 2012). Their failures have been attributed to a potential weakness in the construct or in its measurement (Lamb, 2012; Teimouri, 2017). A suggested remedy is the application of more elaborate measures (Taguchi et al., 2009; Dörnyei \& Chan, 2013) addressing different types of external influences separately.

The questionnaire employed and tested by Taguchi et al. (2009) includes, apart from the scales targeting exclusively the ideal L2 self, the ought-to L2 self, the L2 learning experience and the motivated L2 learning behaviour (which is also termed criterion measure, or intended effort), scales dealing with promotional (i.e. framed in a positive way) and preventional (framed in a preventive way) instrumental motives, and scales addressing affective factors such as fear of assimilation, English language learning anxiety and ethnocentrism (Taguchi et al., 2009). The questionnaire has predominantly 
been used in large-scale studies (Taguchi et al., 2009; Papi, 2010; You \& Dörnyei, 2016). It could be equally valuable, though, in small-scale teacher-led studies - it can give a snapshot of own students' motivation, which could stimulate teacher's reflections and actions, and/or further research.

In Bulgarian context, although the importance of L2 motivation for language learning has been recognised, and paradigms of L2 motivation have been analysed (Popandonova, 2009; Shopov, 2013, pp. 243-248; Shopov \& Sofronieva, 2018, pp. 4345), the literature search reveals few publications of empirical studies, and none of them follows any of the approaches described above. Pehlivanova (2011), for example, adopts a qualitative stance in her survey of L2 motivation and demotivation of fifty university students. The survey results suggest three factors defining her students' motivation: parents' role, language teacher's role and the opportunity to build on language knowledge and skills (Pehlivanova, 2011, p.15). Interestingly enough, parents' influence, the teacher's personality and the strive for self-development are among the least frequently mentioned L2 motives in another qualitative survey of 204 school students (Markova, 2016, p. 38). In this study, the top three L2 motivational factors referred to are the intrinsic interest in English as a language, the perceived importance of English and the desire to communicate with foreigners (Markova, 2016, p. 37). Other factors are related to students' future plans and to their interest in classroom activities and topics, which allows of some parallels between the findings of the latter study and the eight motivational dimensions in Ushioda's model (2001). Ruzhekova-Rogozherova (2014), by contrast, takes a quantitative-research approach in a survey of her university students' L2 motivation (the number of the survey participants is not provided). The survey findings indicate that communication and internet use are recognised as motivating factors by $94.45 \%$ of the respondents, whereas the sense of success, receiving $52.78 \%$ of the responses, is found to be the least frequently mentioned factor (Ruzhekova-Rogozherova, 2014, p. 24).

Below follows a description of a small-scale survey aiming to define the L2 motivational characteristics of Bulgarian students of International Relations in order to find out if they are similar to the motivational patterns described in other studies or there are differences that can be related to the learners' profile. 


\section{Method}

\section{Participants}

The survey participants were 19 - 21-year-old students majoring in International Relations at a Bulgarian university who had chosen to study English as a first foreign language. Participation was voluntary and anonymous. The data collection took place at the beginning of the academic year. The average time needed for taking the survey was fifteen minutes. After the elimination of inadequately completed questionnaires the sample included thirty-one students - sixteen females and fifteen males.

\section{Instrument}

The Iranian version of the questionnaire used in Taguchi et al.'s (2009) study was considered most appropriate for data collection in the present research context. Still, this version was slightly adapted: items 31, 46 and 52 in the original questionnaire, addressing beliefs related to Islam and Islamic culture, were omitted as irrelevant to a Bulgarian university context. Thus, the questionnaire employed in this study (Appendix A) consists of 73 six-level Likert items, which range from strongly disagree (1) to strongly agree (6) for the statements in Part I, and from not at all (1) to very much (6) for the questions in Part II. The items target fourteen motivation variables, which are summarised in Table 1.

\section{Table 1}

Motivation variables

\begin{tabular}{|c|c|c|}
\hline Variables & Item № & Sample items \\
\hline Criterion measure & $\begin{array}{l}8,16,24,31 \\
39,48\end{array}$ & I would like to study English even if I were not required. \\
\hline Ideal L2 self & $\begin{array}{l}9,17,25,32 \\
40,49\end{array}$ & $\begin{array}{l}\text { I can imagine myself living abroad and using English } \\
\text { effectively for communicating with the locals. }\end{array}$ \\
\hline Ought-to L2 self & $\begin{array}{l}1,10,18,26 \\
33,42\end{array}$ & $\begin{array}{l}\text { Studying English is important to me because other people } \\
\text { will respect me more if I have a knowledge of English. }\end{array}$ \\
\hline $\begin{array}{l}\text { Parental } \\
\text { encouragement/ } \\
\text { family influence }\end{array}$ & $\begin{array}{l}2,11,19,27 \\
34,43\end{array}$ & $\begin{array}{l}\text { My parents/family believe(s) that I must study English to } \\
\text { be an educated person. }\end{array}$ \\
\hline $\begin{array}{l}\text { Instrumentality- } \\
\text { promotion }\end{array}$ & $\begin{array}{l}3,12,20,28 \\
36,44\end{array}$ & $\begin{array}{l}\text { Studying English can be important to me because I think it } \\
\text { will someday be useful in getting a good job and/or } \\
\text { making money. }\end{array}$ \\
\hline $\begin{array}{l}\text { Instrumentality - } \\
\text { prevention }\end{array}$ & $\begin{array}{l}4,13,21,29 \\
35,41,46,50\end{array}$ & $\begin{array}{l}\text { I have to study English; otherwise, I think I cannot be } \\
\text { successful in my future career. }\end{array}$ \\
\hline
\end{tabular}


Attitudes towards learning English

Travel orientation

Fear of assimilation

Ethnocentrism

English anxiety

Integrativeness

Cultural interest

Attitudes towards L2 community
$51,56,60,64$, Do you like the atmosphere of your English classes? 68,72

35, 30, 45 I study English because with English I can enjoy travelling abroad.

$6,14,22,37$, I think the cultural and artistic values of English are going 47 at the expense of Bulgarian values.

$7,15,23,38$ It would be a better world if everybody lived like the Bulgarian.

$52,57,61,65$, How afraid are you of sounding stupid in English because 69,73 of the mistakes you make?

53, 66, $70 \quad$ How much do you like English?

$54,58,62,71$ Do you like the music of English-speaking countries (e.g. pop music)?

55, 59, 63, 67 Do you like to travel to English-speaking countries?

\section{Results and Discussion}

\section{Descriptive analysis}

Table 2 presents the mean values of the motivation variables of the whole group and of the female and male subgroups.

\section{Table 2}

Mean values of the motivation variables

\begin{tabular}{lccc}
\hline \multicolumn{1}{c}{ Variable } & Total & Female & Male \\
\hline Criterion measure (intended effort) & 4.56 & 4.93 & 4.17 \\
Ideal L2 self & 5.25 & 5.39 & 5.12 \\
Ought-to L2 self & 3.19 & 3.49 & 2.88 \\
Parental encouragement/ Family influence & 3.43 & 3.75 & 3.05 \\
Instrumentality - promotion & 4.93 & 5.01 & 4.85 \\
Instrumentality - prevention & 4.08 & 4.26 & 3.91 \\
Attitudes towards learning English & 4.92 & 5.17 & 4.67 \\
Travel orientation & 5.12 & 5.43 & 4.82 \\
Fear of assimilation & 3.14 & 3.18 & 3.1 \\
Ethnocentrism & 2.79 & 3.12 & 2.46 \\
English anxiety & 2.79 & 3.12 & 2.46 \\
Integrativeness & 4.77 & 4.76 & 4.79 \\
Cultural interest & 5.3 & 5.62 & 4.99 \\
Attitudes towards L2 community & 4.8 & 5.16 & 4.44 \\
\hline
\end{tabular}


With the exception of factors 10-11 (i.e. ethnocentrism and English anxiety), whose scores fall on the negative side of the continuum, the mean values range from 3.14 to 5.3. For most of the factors (nine out of eleven), they exceed the midpoint of 3.5, which suggests that the surveyed group in general has a positive attitude towards English language learning. This is further evidenced by the high mean value for the criterion measure (4.56). Within this variable, the highest score (5.15) is for item 'I would like to study English even if I were not required'.

The highest mean values, however, are obtained for factors associated with the ideal L2 self domain: cultural interest (5.3), ideal L2 self (5.25) and travel orientation (5.12). These findings are not surprising given the profile of the respondents - students of International Relations whose future career would entail intercultural communication and travel dependent on their good command of English. The lowest mean values are connected with the affective factor 'fear of assimilation' (3.14), and with the ought-to L2 self domain - 3.19 for the ought-to self and 3.43 for parental encouragement. The next lowest mean value is for instrumentality-prevention (or the desire to avoid failure), which is also associated with the ought-to L2 self domain (You \& Dörnyei, 2016). Yet, the scores for this factor, with a mean value of 4.08, definitely fall on the positive side of the continuum. With respect to the latter results, the present study corresponds to the survey conducted by You and Dörnyei (2016), where the ought-to L2 self domain also produced the lowest scores.

The survey data show consistent gender differences, which is in tune with the pattern found in empirical studies from different sociocultural contexts (Henry, 2011; Henry \& Cliffordson, 2013; You \& Dörnyei, 2016). There is no particular correspondence, however, between the descriptive statistics of the present study and the findings of the Bulgarian surveys discussed above.

\section{Correlation analysis}

The long-lasting interest in L2 learning motivation is closely connected with its relation to language learning. Whereas survey data cannot really explain how (or even whether) motivation influences actual learning behaviour, they allow us to examine the 
associations between the motivation factors and the criterion measure, i.e. intended effort. The motivation-effort correlations are presented in table 3. Intended effort correlates most strongly with attitudes towards learning English $(r=0.68)$ and cultural interest $(r=0.68)$. These results suggest that, even at a university level, the positive evaluation of the process of learning English matters as it is closely associated with the willingness to put effort into language learning. They are corroborated by previous research findings (Lamb, 2012; You \& Dörnyei, 2016), where the factor attitudes towards learning English has the strongest correlation with intended effort. The survey data analysis also indicates a moderate to strong correlation between intended effort and travel orientation $(r=0.65)$, and attitudes towards L2 community $(r=0.65)$. At this point, it might be useful to remember that the mean values of cultural interest (5.3) and travel orientation (5.12) rank correspondingly first and third among the motivational factors for the surveyed group. Attitudes towards the L2 community, though not among the top three, still obtain a high mean score -4.80 on the positive side of the motivation continuum. All these findings suggest that the motivational variables which are closely associated with respondents' future careers in international relations bear relevance to their engagement with language learning.

At the same time, with correlation coefficients of 0.58 and 0.56 , ideal L2 self (second mean score of 5.25) and instrumentality-promotion (fourth mean score of 4.93), correlate more highly with intended effort than ought-to L2 self and the variables it is associated with. Additionally, integrativeness (mean score of 4.77 on the positive side of the continuum) also displays significant moderate correlation with intended effort $(r=0.40)$. These findings come to confirm the observation that the extent of students' involvement in language learning is closely linked to the motivational factors that are meaningful for them. They are expectedly in tune with the results of previous studies confirming the role of the ideal L2 self as a strong predictor of different criterion measures connected with language learning (for a concise summary, see Dörnyei \& Chan, 2019). Besides, the survey results agree with the findings of Taguchi et al. (2009, p.78), who reported higher correlations between the criterion measure and the ideal L2 self than between the criterion measure and integrativeness. 


\section{Table 3}

Correlations between the motivational variables and intended effort

\begin{tabular}{|c|c|c|c|c|c|c|c|c|c|c|c|c|}
\hline 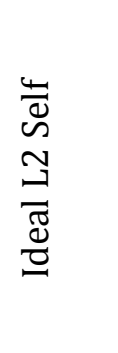 & 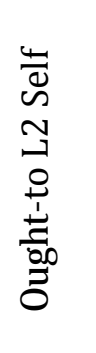 & 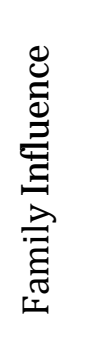 & 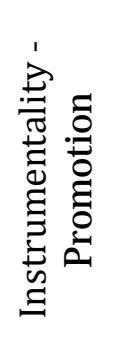 & 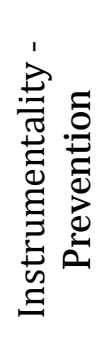 & 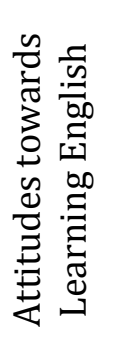 & 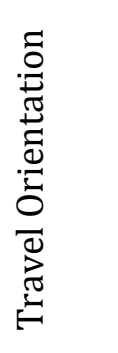 & 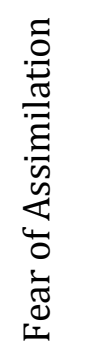 & 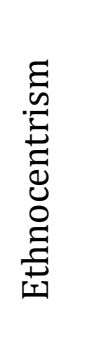 & 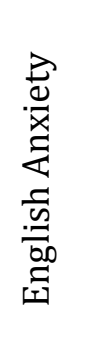 & 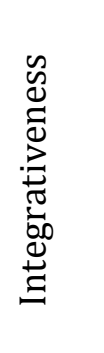 & 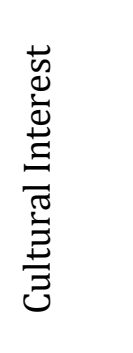 & 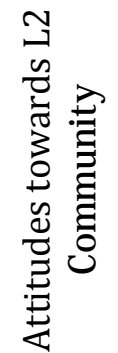 \\
\hline $0,58^{\text {** }}$ & 0.17 & 0.25 & $0.56^{* *}$ & 0.24 & $0.68^{* *}$ & $0.65^{* *}$ & -0.31 & 0.11 & 0.33 & $0.40^{*}$ & $0.68^{* *}$ & $0.65^{* *}$ \\
\hline
\end{tabular}

Note: ${ }^{*} \mathrm{p}<.05$ (2-tailed), ${ }^{* *} \mathrm{p}<.01$ (2-tailed).

Table 4 shows how the ideal L2 self relates to the other motivational variables. Similarly to the results of Taguchi et al. (2009, p. 77), the present analysis reveals a correlation over 0.50 between the ideal L2 self and integrativeness. The correlation coefficients for Japan, China and Iran are correspondingly $0.59,0.51$ and 0.53 ; for the surveyed group of Bulgarian students the coefficient is 0.59 - these results imply that the two variables could be tapping into the same construct domain (Dörnyei, 2009, pp. 27-28; Taguchi et al., 2009, p.77). The strongest positive correlation for the surveyed group, however, is between the ideal L2 self and attitudes towards the L2 community (0.67). This result is not surprising - as Dörnyei $(2009$, p.28) points out, “... it is difficult to imagine that we can have a vivid and attractive L2 self if the L2 is spoken by a community we despise". The second strongest correlation in this analysis $(r=0.65)$, between the ideal L2 self and instrumentality-promotion, gives further evidence for the promotion focus of the ideal self-guide (Higgins, 1998; Dörnyei, 2009, pp. 27-28). The latter result also corresponds with the findings of Taguchi et al. $(2009$, p.79), where the obtained correlation coefficients for Japan, China and Iran are 0.60, 0.46 and 0.63 respectively. In general, the analysis reveals moderate to strong correlations between the ideal L2 self and the motivational variables it is associated with - instrumentalitypromotion, travel orientation, integrativeness, cultural interest and attitudes towards L2 community (Dörnyei, 2009) - once again confirming the relationship between these constructs. An interesting aspect of this study is the moderate correlation (0.49) between the ideal L2 self and the attitudes towards learning English, which suggests that, for the surveyed group, positive attitudes towards learning the language are closely linked to students' ideal L2 selves. 
Another interesting correlation, or lack thereof in this analysis, is the zero correlation between the ideal L2 self and family influence - an indication of the absence of any relation between the two constructs. This result is supported by previous research which links family influence to the ought-to L2 self, not to the ideal L2 self (Taguchi et al., 2009).

\section{Table 4}

Correlations between the motivational variables and ideal L2 self

\begin{tabular}{|c|c|c|c|c|c|c|c|c|c|c|c|c|}
\hline 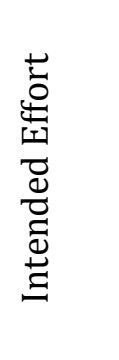 & 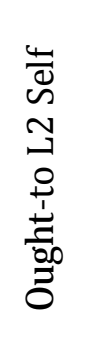 & 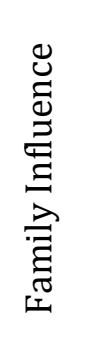 & 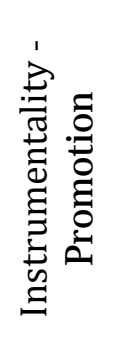 & 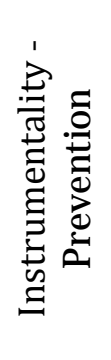 & 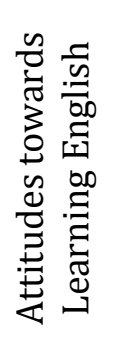 & 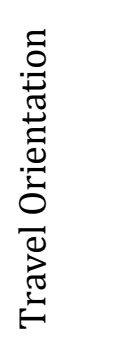 & 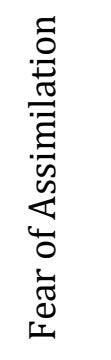 & 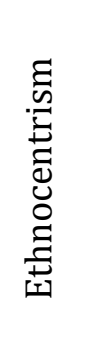 & 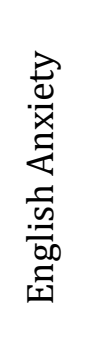 & 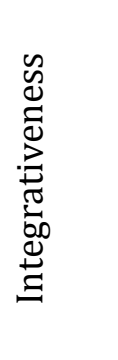 & 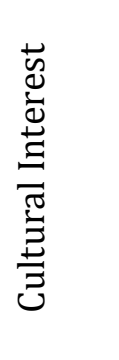 & 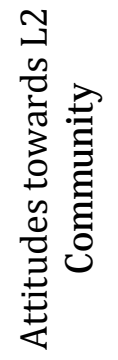 \\
\hline $0.58^{* *}$ & 0.13 & 0.00 & $0.65^{* *}$ & 0.19 & 0.49 ** & $0.54^{* *}$ & -0.33 & -0.14 & -0.10 & $0.59 * *$ & $0.56^{* *}$ & $0.67^{* *}$ \\
\hline
\end{tabular}

Note: ${ }^{* *} \mathrm{p}<.01(2$-tailed).

The correlations between the ought-to L2 self and other motivational variables are illustrated in table 5. The motivation factors that correlate most strongly with the ought-to L2 self are family influence (0.71) and instrumentality-prevention (0.67), which supports the premises that the ought-to self-guide entails motives that are spurred by parents and therefore less internalised, and that often have a prevention focus (Higgins, 1998; Dörnyei, 2009, pp. 27-28). As regards instrumentality-prevention, similar results are reported by Taguchi et al. (2009, p. 79), who found correlation coefficients of 0.68 and 0.62 for the Chinese and Iranian contexts, and a less strong correlation $(r=0.45)$ for the Japanese context. There is a substantial correlation $(r=0.42)$ between the ought-to self and the instrumentality-promotion, which again corresponds with the findings of Taguchi et al. (2009, p. 79). They report similar correlations between the ought-to self and the instrumentality-promotion 0.46 for the Chinese context, 0.44 for the Iranian context), and interpret them within the typical family relationships of the two countries, where parents invest a lot in their children and expect similar attitude in return. Although Bulgarian culture and way of life may seem rather different from those of China and Iran, the specifics of Bulgarian parents' expectations and aspirations regarding their children's success in life might similarly 
serve as an explanation of this correlation. This interpretation is supported by other significant correlations (Table 6) - between family influence (which is closely related to the ought-to L2 self) and instrumentality-promotion ( $r=0.45)$, and between family influence and instrumentality-prevention $(r=0.54)$. These findings provide an additional angle for the relationships between the ought-to L2 self and instrumentality.

A different explanation of the substantial correlation between the ought-to L2 self and instrumentality-promotion can be found in the claim that there are problems with the measurement of the ought-to 12 self due to a mix of positive and negative end outcomes included in the questionnaire items (Teimouri, 2017, p. 686). According to Teimouri (2017, p. 686), items such as 'If I fail to learn English, I'll be letting other people down' reflect the sensibility of the ought-to self to the presence or absence of negative outcomes, whereas items like 'Studying English is important to me because other people will respect me more if I have a knowledge of English' are related to the presence or absence of positive outcomes. Thus, the latter are more relevant to the measurement of the ideal L2 self than the ought-to self.

The substantial correlation $(r=0.47)$ between the ought-to L2 self and the travel orientation is also open to interpretations. Again, it could be explained with the discussed above mix of questionnaire items. Taking into account the profile of the surveyed group (students of International Relations), though, could lead us to another explanation - this particular type of respondents could relate travelling to their desire to meet expectations associated with a career in international relations, and thus to the ought-to self. Similar concerns reflecting the importance of English for students' future careers are reported in a qualitative research study focusing on the L2/L3 future selves in Thai context (Siridetkoon \& Dewaele, 2017).

The final two significant correlations - $(r=0.51)$ between the ought-to L2 self and ethnocentrism, and $(r=0.40)$ between the ought-to L2 self and English anxiety - are not surprising. As ethnocentrism entails biased judgement of other cultures based on the belief that one's own culture is superior (LeVine, 2015, p. 166), it could be associated with the more extrinsic instrumental motives for studying English that the ought-to L2 self pertains to. This aspect of the analysis corresponds with the findings of a study of 47 Japanese university students, where the correlation coefficient between the ought-to L2 self and 
ethnocentrism is 0.44 (Apple \& Aliponga, 2018, pp. 289-308). As for the correlation between the ought-to L2 self and English anxiety, it confirms the assumption that less internalised instrumental motives to study English are more likely to be related to higher levels of language anxiety. This result is corroborated by similar correlations in previous research on the topic (Papi, 2010; MacWhinnie \& Mitchell, 2017; Teimouri, 2017).

\section{Table 5}

Correlations between the motivational variables and ought-to L2 self

\begin{tabular}{|c|c|c|c|c|c|c|c|c|c|c|c|c|}
\hline 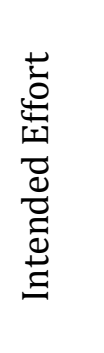 & 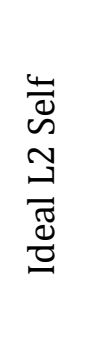 & 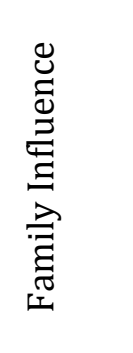 & 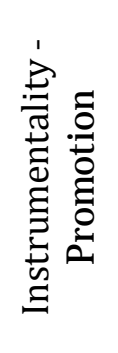 & 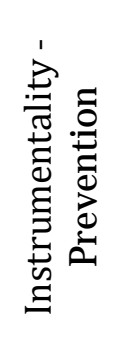 & 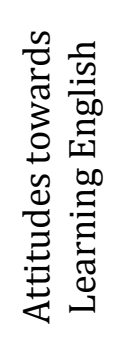 & 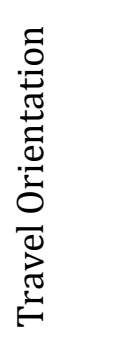 & 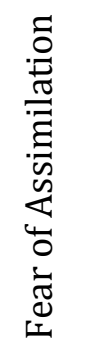 & 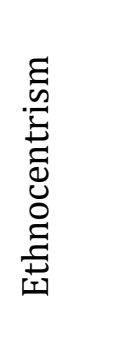 & 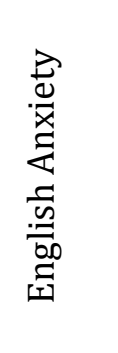 & 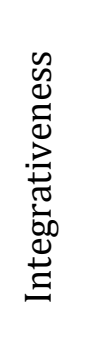 & 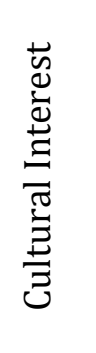 & 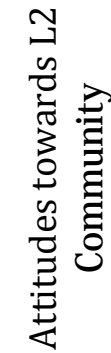 \\
\hline 0.17 & 0.13 & $0.71^{* *}$ & $0.42^{*}$ & $0.67 * *$ & 0.01 & $0.47 * *$ & 0.16 & $0.51^{* *}$ & $0.40^{*}$ & 0.27 & 0.22 & 0.22 \\
\hline
\end{tabular}

Note: ${ }^{*} \mathrm{p}<.05$ (2-tailed), ${ }^{* *} \mathrm{p}<.01$ ( 2 -tailed).

Previous research has found that parental encouragement contributes to students' learning behaviour in a positive way (Csizér \& Lukács, 2010). Although the correlation between intended effort and parental encouragement in the present analysis is weak and non-significant, a look at how family influence correlates with the motivational variables that have not been discussed yet (table 6) could provide a more nuanced picture of the L2 motivational self system of the surveyed group. Apart from the substantial correlations with the two types of instrumentality discussed above, family influence has a moderate correlation with English anxiety $(r=0.48)$, ethnocentrism $(r=0.42)$ and cultural interest $(r=0.38)$. Among these, the first is perhaps the more logical to expect as language anxiety could be associated with aspirations and values that are more internal to the parents than to their children - an assumption that has been validated in an Iranian high-school context (Papi, 2010). The values of the other two correlation coefficients are similar although they seem to refer to opposite or near-opposite concepts - notwithstanding this opposition, these correlations indicate a connection between family influence and attitudes to other cultures. 


\section{Table 6}

Correlations between the motivational variables and parental encouragement/family influence

\begin{tabular}{|c|c|c|c|c|c|c|c|c|c|c|c|c|}
\hline 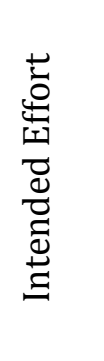 & 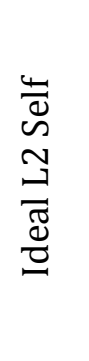 & 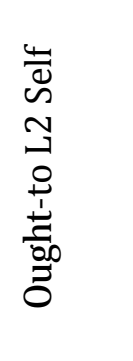 & 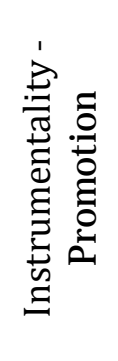 & 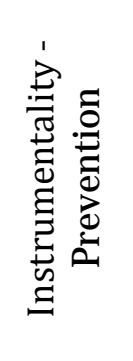 & 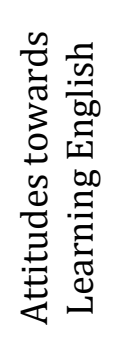 & 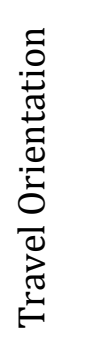 & 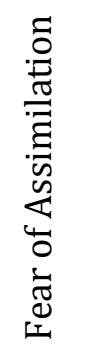 & 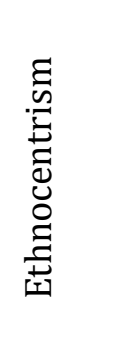 & 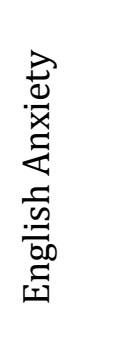 & 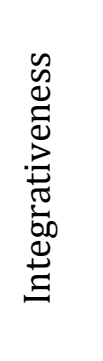 & 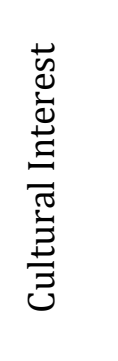 & 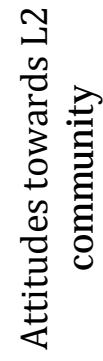 \\
\hline 0.25 & 0.00 & $0.71^{* *}$ & $0.45^{*}$ & $0.52^{* *}$ & 0.04 & 0.42 & 0.24 & $0.42 *$ & $0.48^{* *}$ & 0.19 & $0.38 *$ & 0.19 \\
\hline
\end{tabular}

Note: ${ }^{*} \mathrm{p}<.05$ (2-tailed), ${ }^{* *} \mathrm{p}<.01$ ( 2 -tailed).

Table 7 and table 8 provide details about the correlations between the motivational variables and the two types of instrumentality which could shed further light on the specifics of the relationship between the ought-to L2 self and the two aspects of instrumentality of the surveyed group. The correlation coefficients suggest substantial connections between instrumentality-promotion and travel orientation $(r=0.56)$, cultural interest $(r=0.50)$, and integrativeness $(r=0.46)$ on the one hand (Table 7), and between instrumentality-prevention and English anxiety ( $\mathrm{r}=0.41)$, and ethnocentrism $(\mathrm{r}=0.40)$, on the other hand (Table 8). Additionally, Table 7 indicates moderate correlations between instrumentality-promotion and attitudes towards learning English ( $r=0.39)$ and attitudes towards L2 community $(r=0.36)$. What is not in accordance with the L2 Motivational Self System, but is suggested by the correlation between the ought-to L2 system and instrumentality-promotion discussed above, is the substantial intercorrelation between instrumentality-promotion and instrumentality-prevention $(r=0.54)$. This result hints that the two aspects of instrumentality are not discrete enough for the surveyed group - a fact that could be interpreted as either a lack of sufficient internalisation of students' promotional motives or an inclination to satisfy their promotional motives through prevention-focus regulation. The latter interpretation could be supported by the substantial correlations (Table 8) between instrumentalityprevention and two variables typically associated with promotional motives: travel orientation $(\mathrm{r}=0.39)$ and cultural interest $(\mathrm{r}=0.36)$, and can be attributed to respondents' profile - students of International Relations. As Taguchi et al. (2009, p.82) 
suggest, instrumentality items can be perceived differently depending on the context: studying English for going abroad could be promotional for those who want to study abroad, but it could be preventional for those for whom working abroad is part of their future jobs. Whatever the explanation, this feature of the L2 motivational profile of the surveyed group merits more exploration, perhaps through qualitative research instruments.

\section{Table 7}

Correlations between the motivational variables and instrumentality-promotion

\begin{tabular}{|c|c|c|c|c|c|c|c|c|c|c|c|c|}
\hline 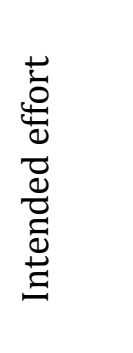 & 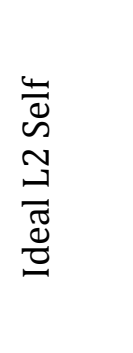 & 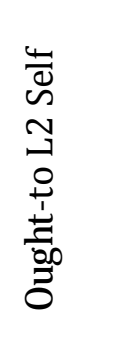 & 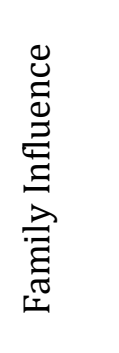 & 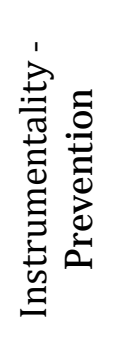 & 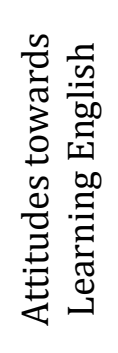 & 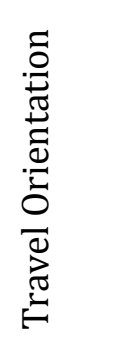 & 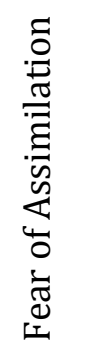 & 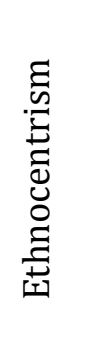 & 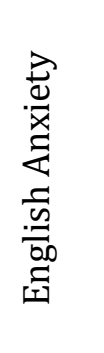 & 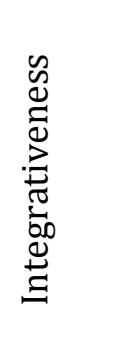 & 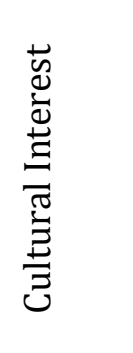 & 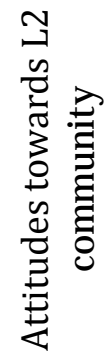 \\
\hline $0.56^{* *}$ & $0,65^{* *}$ & $0.42^{*}$ & $0.45^{*}$ & $0.54^{* *}$ & 0.39* & $0.56^{* *}$ & 0.16 & 0.22 & 0.08 & $0.46^{* *}$ & $0.50 * *$ & $0.36^{*}$ \\
\hline
\end{tabular}

Note: ${ }^{*} \mathrm{p}<.05$ (2-tailed), ${ }^{* *} \mathrm{p}<.01$ (2-tailed).

\section{Table 8}

Correlations between the motivational variables and instrumentality-prevention

\begin{tabular}{|c|c|c|c|c|c|c|c|c|c|c|c|c|}
\hline 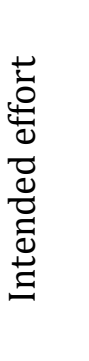 & 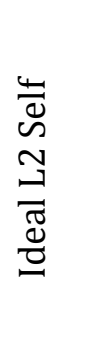 & 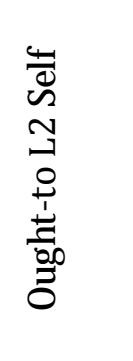 & 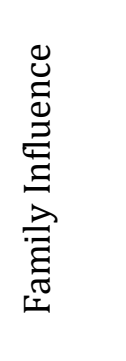 & 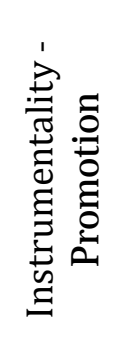 & 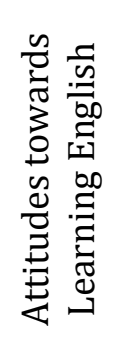 & 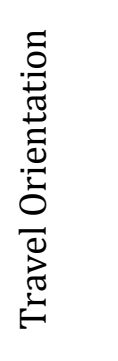 & 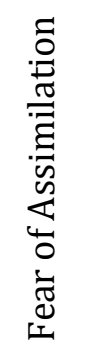 & 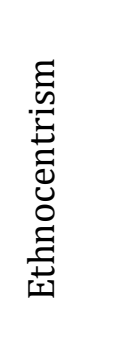 & 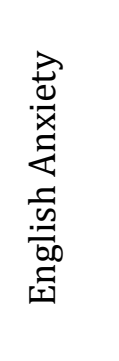 & 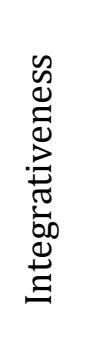 & 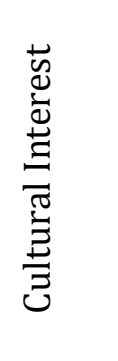 & 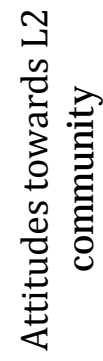 \\
\hline 0.24 & 0,19 & $0.67 * *$ & $0.52^{* *}$ & $0.54^{* *}$ & 0.14 & 0.39* & 0.16 & $0.40^{*}$ & $0.41 *$ & 0.23 & $0.36^{*}$ & 0.21 \\
\hline
\end{tabular}

Note: ${ }^{*} \mathrm{p}<.05$ (2-tailed), ${ }^{* *} \mathrm{p}<.01$ (2-tailed).

\section{Conclusion}

The present study has several limitations. First, all the data come from students at only one university and may not be representative. Second, the survey participation has been voluntary, and the number of respondents, although sufficient for statistical 
analysis, does not allow of generalisation. Third, the use of self-reported questionnaires as research instruments has its weaknesses - response fatigue and social desirability bias are just two examples. Therefore, caution is needed when extrapolating from this small-scale study to other contexts.

Still, the study offers a nuanced picture of the language learning motivation of students of International Relations at a Bulgarian university. Its findings are in broad agreement with those of examinations of the L2 Motivational Self System in other countries. Consistent with previous results (Lamb, 2012; You \& Dörnyei, 2016), the study participants score high on the criterion measure and on factors associated with the ideal L2 self domain, while factors related to the ought-to L2 self domain receive lower scores. Similarly to other studies (Taguchi et al., 2009; You \& Dörnyei, 2016), the reported attitudes towards learning English and ideal L2 self are found to be strongly connected to motivated L2 learning behaviour. The promotional focus of the ideal L2 self and the preventive aspect of the ought-to L2 self (Dörnyei, 2009; Taguchi et al., 2009) have once again found support in this study. Also, in tune with previous research (Papi, 2010), the affective factors are more substantially correlated to factors associated with the ought-to L2 self than to those related to the ideal L2 self.

Like previous research (Csizér \& Lukács, 2010; Lamb, 2012), this study has been unable to resolve the doubt over the relation of the ought-to L2 self to the intended learning effort. Although the recommended, more elaborate measure (Taguchi et al., 2009; Dörnyei \& Chan, 2013) was employed, the correlation between the ought-to L2 self and the criterion measure is low and non-significant. Additionally, in contrast to the premise of the L2 Motivational Self System, but in correspondence to the findings of Taguchi et al. (2009), a substantial correlation between the ought-to L2 self and promotional instrumentality has been arrived at. This inconsistency could be explained by the cultural specifics of family relations and expectations, but it could be also a sign of the ambiguity of the construct.

The analysis has revealed several motivational characteristics of the surveyed students that could be related to aspects of their profile connected with their future careers in international relations. There is a substantial correlation between the travel orientation, typically considered within the ideal L2 self domain, and the ought-to L2 
self. The most unexpected result, however, is the significant intercorrelation between instrumentality-promotion and instrumentality-prevention. These findings suggest a prevention-focus approach to motives typically perceived as promotional which, however, could be interpreted as preventive by people who see travel, cultural interest and working abroad as integral to their future duties. More thorough, qualitativeapproach investigation could provide a better understanding of this feature of the motivational profile of the surveyed group.

The study bears several practical implications. First, it offers evidence that, even at university level, individual teachers and the way they construct learning experiences are closely linked to their students' motivated behaviour. Second, it provides a detailed picture of the motivational characteristics of the Bulgarian students of International Relations which could stimulate their teachers to create learning conditions maximising learners' involvement. Last but not least, the outlined motivational profile - if shared with the students - may trigger students' self-reflection, enhance their self-awareness, and thus contribute to their personal and professional development.

\section{References}

Al-Shehri, A. S. (2009). Motivation and vision: The relation between the ideal L2 self, imagination and visual style. In Z. Dörnyei \& E. Ushioda (Eds.), Motivation, language identity and the L2 self (pp. 164-171). Multilingual Matters. https:// doi.org/ 10.21832/ $9781847691293-009$

Apple, M. T., \& Aliponga, J. (2018). Intercultural communication competence and possible L2 selves in a short-term study abroad program. In I. Walker, D. Chan, M. Nagami \& C. Bourguignon (Eds). New perspectives on the development of communicative and related competence in foreign language education (pp. 289308). De Gruyter, https:/ / doi.org/ 10.1515/9781501505034-012

Csizér, K., \& Kormos, J. (2009). Learning experiences, selves and motivated learning behaviour: A comparative analysis of structural models for Hungarian secondary and university learners of English. In Z. Dörnyei \& E. Ushioda (Eds.), Motivation, language identity and the L2 self (pp. 98-119). Multilingual Matters. https:// doi.org/ 10.21832/ 9781847691293-006

Csizér, K., \&Lukács, G. (2010). The comparative analysis of motivation, attitudes and selves: The case of English and German in Hungary. System, 38, 1-13. https:// doi.org/ 10.1016/j.system.2009.12.001

Crookes, G., \& Schmidt, R. (1991). Motivation: Reopening the research agenda. Language Learning, 41(4), 469-512. https:// doi.org/ 10.1111/j.1467-1770.1991.tb00690.x 
Desi, E. L., \&Ryan, R. M. (1985). Intrinsic motivation and self-determination in human behaviour. Plenum Press. https:// doi.org/10.1007/978-1-4899-2271-7

Dörnyei, Z. (2009). The L2 motivational self system. In Z. Dörnyei \& E. Ushioda (Eds.), Motivation, language identity and the L2 self (pp. 9-42). Multilingual Matters. https:// doi.org/ 10.21832/ 9781847691293-003

Dörnyei, Z. (2010). The relationship between language aptitude and language learning motivation: Individual differences from a dynamic systems perspective. In E. Macaro (Ed.), Continuum companion to second language acquisition (pp. 247267). Continuum.

Dörnyei, Z., \& Chan, L. (2013). Motivation and vision: An analysis of future L2 self images, sensory styles, and imagery capacity across two target languages, Language Learning, 63, 437-62. https:// doi.org/10.1111/lang.12005

Dörnyei, Z. \& Ushioda, E. (2013). Teaching and researching: Motivation. Routledge. https:// doi.org/ 10.4324/9781315833750

Ellis, R. (2004). Individual differences in second language learning. In A. Davies \& C. Elder (Eds.), The handbook of applied linguistics (pp. 525-551). Blackwell Publishing. https:/ / doi.org/ 10.1002/9780470757000.ch21

Gardner, R. (1985). Social psychology and second language learning: the role of attitude and motivation. Edward Arnold.

Gardner, R. C., \& Lambert, W. E. (1959). Motivational variables in second-language acquisition. Canadian Journal of Psychology/Revue canadienne de psychologie, 13(4), 266-272. https:// doi.org/10.1037/ h0083787

Henry, A. (2011). Gender differences in L2 motivation: A reassessment. In S. A. Davies (Ed.) Gender gap: Causes, experiences and effects (pp. 81-102). Nova Science.

Henry, A. \& Cliffordson, C. (2013). Motivation, gender, and possible selves. Language Learning, 63, 271-95. https:// doi.org/ 10.1111/lang.12009

Higgins, E.T. (1987). Self-discrepancy: A theory relating self and affect. Psychological Review, 94, 319-340. https:// doi.org/ 10.1037/0033-295X.94.3.319

Higgins, E.T. (1998). Promotion and prevention: Regulatory focus as a motivational principle. Advances in Experimental Social Psychology, 30, 1-46. https:// doi.org/ 10.1016/ S0065-2601(08)60381-0

Higgins, E.T., Klein, R., \& Strauman, T. (1985). Self-concept discrepancy theory: A psychological model for distinguishing among different aspects of depression and anxiety. Social Cognition, 3(1), 51-76.

https:// doi.org/ 10.1521/ soco.1985.3.1.51 
Lamb, M. (2012). A self-system perspective on young adolescents' motivation to learn English in urban and rural settings. Language Learning, 62, 997-1023. https:// doi.org/ 10.1111/j.1467-9922.2012.00719.x

LeVine, R. A. (2015). Ethnocentrism. In J. D. Wright (Ed.) International Encyclopedia of the Social and Behavioral Sciences (2nd ed.) (pp. 166-167). Elsevier. https:/ / doi.org/ 10.1016/ B978-0-08-097086-8.12063-X

MacWhinnie, S. G. B., \& Mitchell, C. (2017). English classroom reforms in Japan: a study of Japanese university EFL student anxiety and motivation. Asian-Pacific Journal of Second Language and Foreign Language Education, 2(1), 1-13. https:// doi.org/ 10.1186/ s40862-017-0030-2

Markova, Z. (2020). The motivation of university students of International Relations to learn English (v1) [Data set]. Mendeley Data. https:// doi.org/ 10.17632/ 69t8tvbwzf.1

Markova Z. (2016). Straight from the horse's mouth: Motivation to learn English, BETA E-Newsletter, 22, 36-46. http:// www.beta-iatefl.org/ cogitoergosum/ wpcontent/ uploads/2016/ 06/BETA E-Newsletter March April 2016.pdf

Markus, H.R., \& Nurius, P. (1986). Possible selves. American Psychologist, 41, 954-969. https:// doi.org/ 10.1037/0003-066X.41.9.954

Masgoret, A.-M., \& Gardner, R. C. (2003). Attitudes, motivation, and second language learning: A metaanalysis of studies conducted by Gardner and associates. Language Learning, 53(1), 123-163. https:// doi.org/ 10.1111/1467-9922.00212

Noels, K. (2001). Learning Spanish as a second language: Learners' orientations and perceptions of their teachers' communication style. Language Learning, 51(1), 107-144. https:// doi.org/10.1111/0023-8333.00149

Noels, K. A., Pelletier, L. G., Clément, R., \& Vallerand, R. J. (2003). Why are you learning a second language? Motivational orientations and self-determination theory. Language Learning, 53(51), 33-64. https:// doi.org/10.1111/1467-9922.53223

Papi, M. (2010). The L2 motivational self system, L2 anxiety and motivated behaviour: A structural equation modeling approach. System, 38(3), 467-479. https:// doi.org/ 10.1016/j.system.2010.06.011

Pehlivanova, P. (2011). Motivatsiya i demotivatsiya pri izuchavane na chuzhd ezik. Pedagogicheski almanah: pedagogièsko spisanie na Velikoturnovski universitet 'Sv. sv. Kiril I Metody' [Motivation and demotivation for learning a foreign language. Pedagogical Almanac: Pedagogical Journal of the University of Veliko Turnovo]. 19(3). 12-19. http:/ / journals.uni-vt.bg/ almanac/ bul/ vol19/ iss3/2

Popandonova, E. (2009). Pedagogicheski izmereniya na motivatsiyata za izuchavane na chuzhd ezik. Nauchni trudove na Rusenskiya universitet [Pedagogical dimensions of motivation to learn a foreign language. Research Publications of the University of Ruse ]. 48(6.2). 190-196. http:// conf.uniruse.bg/ bg/ ?cmd =dPage\&pid =proc09-6.2 
Ruzhekova-Rogozherova, B. (2014). Teaching English language learning strategies at the Todor Kableshkov University of Transport. Mechanics transport communications, 12(3/1). http:// mtc-aj.com/library/985 EN.pdf

Ryan, S. (2009). Self and identity in L2 motivation in Japan: The ideal L2 self and the Japanese learners of English. In Z. Dörnyei \& E. Ushioda (Eds.), Motivation, language identity and the L2 self (pp. 120-143). Multilingual Matters. https:// doi.org/ 10.21832/ 9781847691293-007

Shopov, T. (2013). Pedagogika na ezika [Pedagogy of language]. Sofia University Press.

Shopov, T., \& Sofronieva, E. (2018). Vsichko da stava za pouka [Let all things be done into edifying]. Sofia University Press.

Siridetkoon, P., \& Dewaele, J. M. (2017). Ideal self and ought-to self of simultaneous learners of multiple foreign languages. International Journal of Multilingualism, 15(4), 313-328. https:// doi.org/ 10.1080/ 14790718.2017.1293063

Skehan, P. (1991). Individual differences in second language learning. Studies in Second Language Acquisition, 13, 275-298.

https:/ / doi.org/ 10.1017/ S0272263100009979

Taguchi, T., Magid, M., \& Papi, M. (2009). The L2 motivational self system among Japanese, Chinese and Iranian learners of English: A comparative study. In Z. Dörnyei, \&E. Ushioda (Eds.), Motivation, language identity and the L2 self (pp. 6697). Multilingual Matters. https:// doi.org/10.21832/9781847691293-005

Teimouri, Y. (2017). L2 selves, emotions, and motivated behaviors. Studies in Second Language Acquisition, 39, 681-709. https:// doi.org/ 10.1017/ S0272263116000243

You, C. J., \& Dörnyei, Z. (2016). Language learning motivation in China: Results of a large-scale stratified survey. Applied Linguistics, 37(4), 495-516. https:/ / doi.org/ 10.1093/ applin/ amu046

Ushioda, E. (2001) Language learning at university: Exploring the role of motivational thinking. In Z. Dörnyei \& R. Schmidt (Eds.), Motivation and Second Language Acquisition (pp. 91-124). University of Hawaii Press. 


\section{Appendix A}

\section{English Learner Questionnaire}

This survey is conducted to better understand the thoughts and beliefs of learners of English. Please read each instruction and write your answers. This is not a test, so there are no 'right' or 'wrong' answers and you do not even have to write your name on it. The results of this survey will be used only for research purposes, so please give your answers sincerely. Thank you very much for your help!

\section{Part I}

In this part, we would like you to tell us how much you agree or disagree with the following statements by simply marking a number from 1 to 6 . Please do not leave out any item.

\begin{tabular}{|c|c|c|c|c|c|c|c|c|c|}
\hline $\begin{array}{l}\text { Strongly } \\
\text { disagree }\end{array}$ & Disagree & $\begin{array}{l}\text { Slightly } \\
\text { disagree }\end{array}$ & Slightly agree & \multicolumn{2}{|c|}{ Agree } & & \multicolumn{3}{|c|}{$\begin{array}{l}\text { Strongly } \\
\text { agree }\end{array}$} \\
\hline 1 & 2 & 3 & 4 & \multicolumn{2}{|l|}{5} & & \multicolumn{3}{|c|}{6} \\
\hline \multicolumn{4}{|c|}{$\begin{array}{l}\text { (Ex.) If you strongly agree with the following statement, write this: } \\
\text { I like skiing very much. }\end{array}$} & 1 & 2 & 3 & 4 & 5 & 6 \\
\hline \multicolumn{4}{|c|}{$\begin{array}{l}\text { 1. I study English because close friends of mine think it is } \\
\text { important. }\end{array}$} & 1 & 2 & 3 & 4 & 5 & 6 \\
\hline \multicolumn{4}{|c|}{$\begin{array}{l}\text { 2. My parents/family believe(s) that I must study English to be an } \\
\text { educated person. }\end{array}$} & 1 & 2 & 3 & 4 & & \\
\hline \multicolumn{4}{|c|}{$\begin{array}{l}\text { 3. Studying English can be important to me because I think it will } \\
\text { someday be useful in getting a good job and/or making money. }\end{array}$} & 1 & 2 & 3 & 4 & & \\
\hline \multicolumn{4}{|c|}{$\begin{array}{l}\text { 4. I have to study English because I don`t want to get bad marks in } \\
\text { it. }\end{array}$} & 1 & 2 & 3 & 4 & & \\
\hline \multicolumn{4}{|c|}{$\begin{array}{l}\text { 5. Learning English is important to me because I would like to } \\
\text { travel internationally. }\end{array}$} & & 2 & 3 & 4 & & \\
\hline \multicolumn{4}{|c|}{$\begin{array}{l}\text { 6. I think that there is a danger that Bulgarian people may forget } \\
\text { the importance of Bulgarian culture, as a result of } \\
\text { internationalization. }\end{array}$} & 1 & 2 & 3 & 4 & & \\
\hline \multicolumn{4}{|c|}{$\begin{array}{l}\text { 7. I would be happy if other cultures were more similar to } \\
\text { Bulgarian. }\end{array}$} & 1 & 2 & 3 & 4 & & \\
\hline \multicolumn{4}{|c|}{ 8. I would like to spend lots of time studying English. } & 1 & 2 & 3 & 4 & 5 & \\
\hline \multicolumn{4}{|c|}{$\begin{array}{l}\text { 9. I can imagine myself speaking English as if I were a native } \\
\text { speaker of English. }\end{array}$} & 1 & 2 & 3 & 4 & & \\
\hline \multicolumn{4}{|c|}{ 10. If I fail to learn English, I'll be letting other people down. } & & 2 & 3 & 4 & & \\
\hline \multicolumn{4}{|c|}{$\begin{array}{l}\text { 11. Studying English is important to me in order to bring honours } \\
\text { to my family. }\end{array}$} & 1 & 2 & & 4 & & \\
\hline \multicolumn{4}{|c|}{$\begin{array}{l}\text { 12. Studying English is important to me because English proficiency } \\
\text { is necessary for promotion in the future. }\end{array}$} & & 2 & 3 & 4 & & \\
\hline \multicolumn{4}{|c|}{$\begin{array}{l}\text { 13. I have to learn English because without passing the English } \\
\text { course I cannot get my degree. }\end{array}$} & & 2 & 3 & 4 & & \\
\hline \multicolumn{4}{|c|}{$\begin{array}{l}\text { 14. Because of the influence of the English language, I think the } \\
\text { Bulgarian language is becoming corrupt. }\end{array}$} & & & & & & \\
\hline \multicolumn{4}{|c|}{$\begin{array}{l}\text { 15. Most other cultures are backward compared to my Bulgarian } \\
\text { culture. }\end{array}$} & & & & & & \\
\hline \multicolumn{4}{|c|}{ 16. I am prepared to expand a lot of effort in learning English. } & 1 & 2 & 3 & 4 & & \\
\hline
\end{tabular}




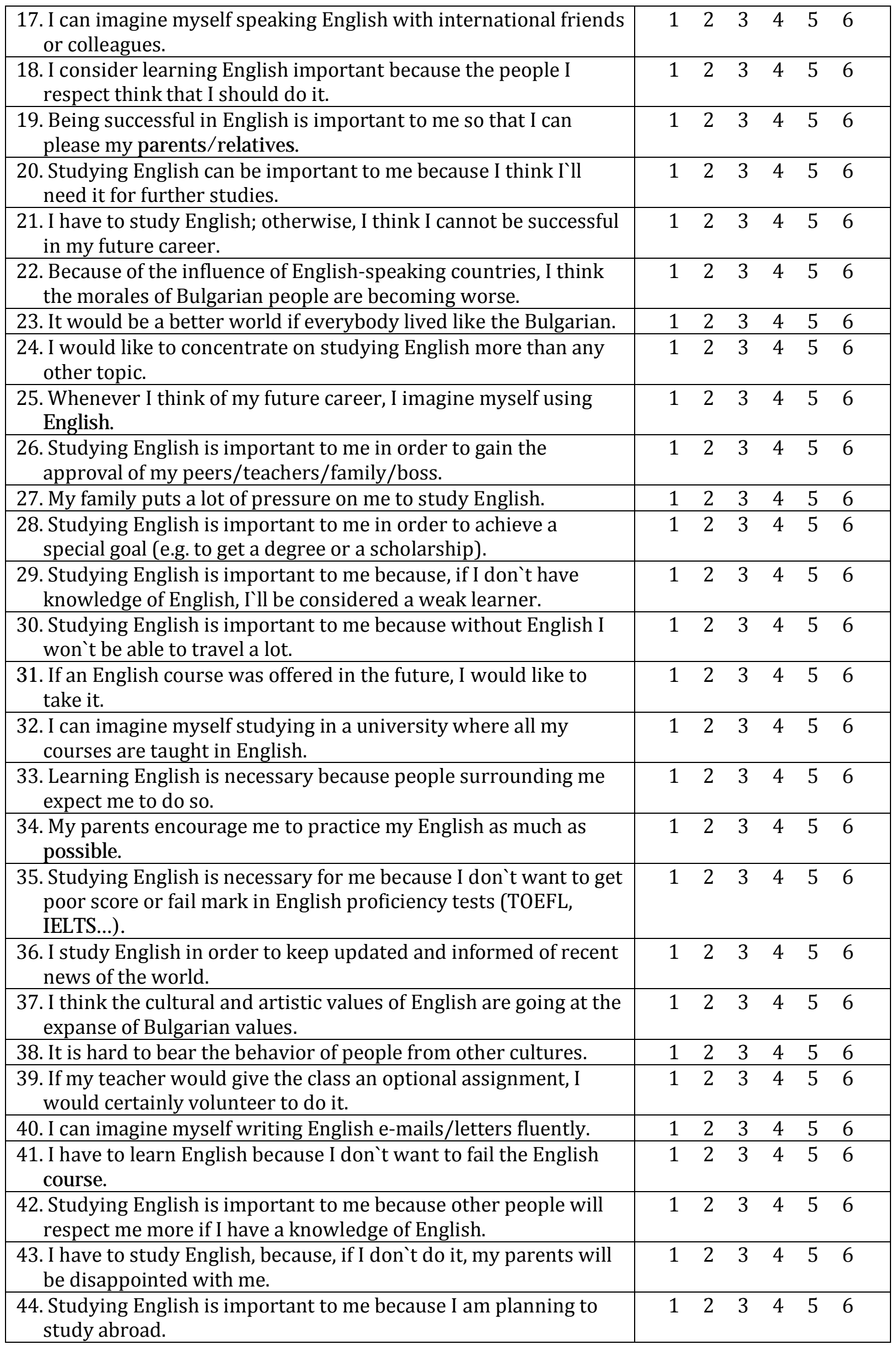




\begin{tabular}{|c|c|c|c|c|c|}
\hline $\begin{array}{l}\text { 45. I study English because with English I can enjoy travelling } \\
\text { abroad. }\end{array}$ & 12 & 3 & 4 & 5 & 6 \\
\hline $\begin{array}{l}\text { 46. Studying English is important to me, because I would feel } \\
\text { ashamed if I got bad grades in English. }\end{array}$ & 1 & 3 & 4 & 5 & $\epsilon$ \\
\hline $\begin{array}{l}\text { 47. I think that, as internationalization advances, there is a danger } \\
\text { of losing the Bulgarian identity. }\end{array}$ & 1 & 3 & 4 & 5 & $\epsilon$ \\
\hline 48. I would like to study English even if I were not required. & 1 & 3 & 4 & 5 & $\epsilon$ \\
\hline $\begin{array}{l}\text { 49. I can imagine myself living abroad and using English effectively } \\
\text { for communicating with the locals. }\end{array}$ & 1 & 3 & 4 & 5 & 6 \\
\hline $\begin{array}{l}\text { 50. Studying English is important to me because I don`t like to be } \\
\text { considered poorly educated person. }\end{array}$ & 1 & 3 & 4 & 5 & 6 \\
\hline
\end{tabular}

\section{Part II}

These are new questions but please answer them the same way as you did before.

\begin{tabular}{|c|c|c|c|c|c|c|c|c|c|}
\hline Not at all & Not so much & So-so & A little & \multicolumn{3}{|c|}{ Quite a lot } & \multicolumn{3}{|c|}{ Very much } \\
\hline 1 & 2 & 3 & 4 & \multicolumn{2}{|l|}{5} & & \multicolumn{3}{|c|}{6} \\
\hline \multicolumn{4}{|c|}{ 51. Do you like the atmosphere of your English classes? } & 1 & 2 & 3 & 4 & 5 & 6 \\
\hline \multicolumn{4}{|c|}{$\begin{array}{l}\text { 52. How tense would you get if a foreigner asked you for directions } \\
\text { in English? }\end{array}$} & 1 & 2 & 3 & 4 & 5 & 6 \\
\hline \multicolumn{4}{|c|}{$\begin{array}{l}\text { 53. How much would you become similar to the people who speak } \\
\text { English? }\end{array}$} & 1 & 2 & 3 & 4 & 5 & \\
\hline \multicolumn{4}{|c|}{$\begin{array}{l}\text { 54. Do you like the music of English-speaking countries (e.g. pop } \\
\text { music)? }\end{array}$} & 1 & 2 & 3 & 4 & 5 & 6 \\
\hline \multicolumn{4}{|c|}{ 55. Do you like the people who live in English-speaking countries? } & & 2 & 3 & 4 & 5 & 6 \\
\hline \multicolumn{4}{|c|}{ 56. Do you find learning English really interesting? } & 1 & 2 & 3 & 4 & 5 & 6 \\
\hline \multicolumn{4}{|c|}{$\begin{array}{l}\text { 57. How uneasy would you feel speaking English with a native } \\
\text { speaker? }\end{array}$} & 1 & 2 & 3 & 4 & 5 & 6 \\
\hline \multicolumn{4}{|c|}{ 58. Do you like English films? } & 1 & 2 & 3 & 4 & 5 & \\
\hline \multicolumn{4}{|c|}{ 59. Do you like meeting people from English-speaking countries? } & 1 & 2 & 3 & 4 & 5 & 6 \\
\hline \multicolumn{4}{|c|}{ 60. Do you think time passes faster while studying English? } & 1 & 2 & 3 & 4 & 5 & 6 \\
\hline \multicolumn{4}{|c|}{$\begin{array}{l}\text { 61. How nervous and confused do you get when you are speaking } \\
\text { in your English class? }\end{array}$} & 1 & 2 & 3 & 4 & 5 & 6 \\
\hline \multicolumn{4}{|c|}{$\begin{array}{l}\text { 62. Do you like TV programmes made in English-speaking } \\
\text { countries? }\end{array}$} & 1 & 2 & 3 & 4 & 5 & 6 \\
\hline \multicolumn{4}{|c|}{ 63. Do you like to travel to English-speaking countries? } & 1 & 2 & 3 & 4 & 5 & 6 \\
\hline \multicolumn{4}{|c|}{ 64. Do you always look forward to English classes? } & 1 & 2 & 3 & 4 & 5 & 6 \\
\hline \multicolumn{4}{|c|}{$\begin{array}{l}\text { 65. How afraid are you of sounding stupid in English because of the } \\
\text { mistakes you make? }\end{array}$} & 1 & & 3 & 4 & 5 & 6 \\
\hline \multicolumn{4}{|c|}{$\begin{array}{l}\text { 66. How important do you think learning English is in order to } \\
\text { learn more about the culture and art of its speakers? }\end{array}$} & 1 & & 3 & 4 & 5 & \\
\hline \multicolumn{4}{|c|}{$\begin{array}{l}\text { 67. Would you like to know more about people from English- } \\
\text { speaking countries? }\end{array}$} & 1 & 2 & 3 & 4 & 5 & 6 \\
\hline \multicolumn{4}{|c|}{ 68. Would you like to have more English lessons at school? } & 1 & 2 & 3 & 4 & 5 & 6 \\
\hline \multicolumn{4}{|c|}{$\begin{array}{l}\text { 69. How worried are you that other speakers of English would find } \\
\text { your English strange? }\end{array}$} & 1 & & & 4 & 5 & 6 \\
\hline \multicolumn{4}{|c|}{ 70. How much do you like English? } & 1 & 2 & 3 & 4 & 5 & 6 \\
\hline \multicolumn{4}{|c|}{ 71. Do you like English magazines, newspapers, or books? } & 1 & 2 & 3 & 4 & 5 & 6 \\
\hline \multicolumn{4}{|c|}{ 72. Do you really enjoy learning English? } & 1 & 2 & 3 & 4 & 5 & 6 \\
\hline \multicolumn{4}{|c|}{$\begin{array}{l}\text { 73. How afraid are you that other students will laugh at you when } \\
\text { you speak English? }\end{array}$} & 1 & & & 4 & 5 & 6 \\
\hline
\end{tabular}

